\title{
Preferable Interior Elements On Instagram Photos At Contemporary Coffee Shops
}

\author{
Setiamurti Rahardjo \\ Program Studi Desain Interior, Fakultas Industri Kreatif, Universitas Telkom \\ Jl Telekomunikasi No 1, Bandung, 40287, Indonesia \\ icusrahardjo@telkomuniversity.ac.id
}

\begin{abstract}
Today we are facing an era where the massive usage of Instagram has been utilized as a means of competitive marketing between hospitality industries, namely coffee shops. The more hashtags of a particular coffee shop indicate its prospect to gain popularity and win the market competition. Instagram users also benefits the coffee shop owners through their personal photo documentations that become a costless marketing. Although there have been numerous discussions about how aesthetic interior design and visual advertising increases the customer visits to coffee shops, there is still a lack of information about specific interior elements that are frequently framed on Instagram photos. Thus, this paper aims to explore interior elements on Instagram photos at contemporary coffee shops in order to find a particular interior element or setting which is more preferable as a photo background or object. This study is performed through the content analysis method with Instagram photo samples of 180 Coffee and Music, Mimiti Coffee and Space, Sejiwa, and Sydwic, all of which have more than a thousand hashtags on Instagram and represent various interior design styles. The result shows vegetation and concrete wall as the most preferred interior elements, accompanied by monochromatic color tone of the furniture or decoration. This result is able to contribute a form of knowledge to both designers and coffee shop owners to keep the continuation of this business industry by giving more considerations on the preferable interior elements.
\end{abstract}

Keywords: interior elements, coffee shop design, instagrammable interior, contemporary coffee shop

\section{Preferensi Elemen Interior Coffee Shop Kontemporer Pada Foto Instagram}

Sekarang ini Instagram sudah banyak digunakan dalam persaingan media marketing di antara berbagai industri bisnis, salah satunya kedai kopi atau populer disebut dengan coffee shop. Semakin banyak tanda tagar yang dimiliki sebuah coffee shop di Instagram sejalan dengan tingkat kepopuleran coffee shop tersebut dan kemungkinannya untuk memenangkan dunia persaingan. Para pengguna Instagram juga mendukung penngusaha dengan unggahan dokumentasi pribadi berupa yang dimanfaatkan sebagai marketing gratis. Meski pembahasan mengenai keterkaitan antara estetika desain interior dan marketing visual dan tingkat ketertarikan pengunjung, namun belum ada ulasan spesifik mengenai elemen interior apakah yang kerap muncul dalam foto-foto Instagram. Dengan demikian, artikel ini bermaksud untuk mengulas elemen interior pada coffee shop di era kontemporer, yang lebih disukai sebagai latar maupun objek foto. Penelitian untuk artikel ini dilakukan dengan metode konten analisis, dengan mengkaji sampel-sample foto dari 180 Coffee and Music, Mimiti Coffee and Space, Sejiwa, and Sydwic. Tempat-tempat tersebut memiliki lebih dari seribu tagar di Instagram dan mewakili penggayaan desain yang berbeda-beda. Penelitian ini memperlihatkan bahwa preferensi elemen interior untuk foto Instagram terletak pada keberadaan vegetasi dan tembok beton, yang disertai dengan penggunaan warna monokrom dari furnitur dan dekorasi yang ada di dalam ruang. Hasil ini kemudian dapat dipergunakan sebagai wawasan bagi desainer maupun pemilik usaha coffee shop untuk mempertimbangkan pengembangan usahanya melalui pengolahan elemen-elemen interior.

Keywords: interior elements, coffee shop design, instagrammable interior, contemporary coffee shop 


\section{INTRODUCTION}

We live in the digital era where social media has become our daily consumptions. The users are not only segmented to the young generations, but also children and older people. Nearly everyone is now familiar to social media as long as they use smartphones in daily basis. Smartphone owners can get most of the applications for free on the apps store, and many smartphones have also come together with installed social media applications, such as Facebook, WhatsApp, and Instagram.

Amongst the many choices, Instagram had become the most used application in today's era of social media (Suess, 2018). Instagram focuses its contents to the display of photos or images and words in the caption of the image. These features allow the users to explore endless opportunities from the application. As we can see now, Instagram is broadly utilized as a promotion media (Çelik, 2017; Agam, 2017), an influencing tool (Kim, et. al, 2017), and a gallery of self- expression (Clara, 2017). These opportunities make people become more creative in presenting their Instagram pages as interesting as possible. Nevertheless, the visual competition between Instagram users also becomes inevitable especially to those who use Instagram as their business marketing platform.

One of the business industries that benefits a lot from Instagram is coffee shop. The growth of coffee shop has been very rapid in these past years (Purnomo, 2018). It is in line with the amount of coffee consumption in Indonesia that has been increasing beyond the number of coffee production (Rosiana, et. al, 2017). Coffee has become a culture and socializing in a coffee shop has become a lifestyle (Rohman and Pang, 2015), especially in more developed cities in Indonesia. With the vast use of Instagram, the exploited coffee culture on social media may influence people to visit the coffee shop if the place looks interesting (Nisak and Hariyanto, 2017).

Undoubtedly, Instagram has become an effective advertising media (Khairani, et. al., 2018). Through posting a photo of a coffee shop on Instagram, it helps the place become known to a wider society (Zappavigna, 2016). As an impact, the coffee shop owners also try to beautify their places as an attempt to create a photogenic atmosphere that will make people excited totake a picture of the place. When the guests post their pictures after visit on Instagram and give a hashtag of the name of the coffee shop on the caption, it becomes a costless marketing that is very beneficial for the business. People then will judge a coffee shop by the number of hashtags and will consider about their visit to the place. Either used as a proud mark that a certain place has been visited or as a good review or recommendation, the use of a hashtag on Instagram indicates a positive image of a place. Thus, coffee shops with more hashtags are more likely to win over the market competition.
On the other hand, the competitive marketing between coffee shops also impact interior designers who help beautify the space. In this contemporary era, interior designers also compete with one another to create a photogenic space for Instagram. The success of the coffee shop will also become the success of the designer since the posted photos on Instagram can be a portfolio for the designer's career.

Although there have been numerous discussions about the role of aesthetic aspects in marketing or customer's satisfaction (Lisdayanti and Anwar, 2018; Hendriyani, 2018), but we are still lacking of information about the specific interior elements that may have important role on Instagram photography. Therefore, this study observes photo samples of contemporary coffee shops on Instagram to find specific interior elements or settings which are more preferable for photo background or object. The samples for this study are taken from photos which expose interior elements through spatial angles or selfies at 180 Coffee and Music, Mimiti Coffee and Space, Sejiwa, and Sydwic, all of which are located in Bandung. Those coffee shops are found with more than a thousand hashtags on Instagram and represent various interior design styles in the contemporary era. The result is expected to give a contribution in a form of knowledge to both designers and coffee shop owners by giving more considerations about preferable interior elements for Instagram photography at the contemporary coffee shops.

\section{LITERATURE REVIEW}

Interior design is a part of architecture which focuses on the inner part of the building. Whether it is classified as interior architecture or interior decoration (Dodsworth, 2009:9), an interior designer is responsible for creating the aesthetic aspect of the interior of the building according to its function and context. More than creating the style, interior design should take "a holistic view of the way that individuals use and enjoy the spaces that they inhabit. It is about finding and creating a cohesive answer to a set of problems and dressing the solution so as to unify and strengthen our experience of the space." (Dodsworth, 2009:8) As a means to answer the necessity of marketing competition on Instagram, interior designers are challenged to create a space that gives a pleasant visual experience through as many cultivated interior elements as possible.

Both of interior design and architecture are tightly attached to space as their main element, but the boundary of interior space is limited by the enclosure of walls, ceilings and floors. All of the spaces created within this boundary are for the interior designers to cultivate. According to Coles and House (2007), an interior space consists of plane, scale, proportion, vista, movement, transition, and accessibility. Although all elements of interior spaces can only be accurately observed through spatial disclosure, elements like planar and vista are able to give visual expe- 
rience related to photography. Their brief explanations are described below:

\section{Planar:}

It is a two-dimensional form employs as floors, walls, and ceilings that define space, as well as smaller planar elements, such as

doors, stairs, shelves, furniture, etc.

Vista:

It is an extended and framed outlook from key viewpoints that usually connects internal and external spaces, such as an outdoor view framed by a window.

Other than spatial elements, the context of interior design also consists of limitless objects that fill the space to give function, style, and identity. These complementary elements can be categorized as furniture, wall treatment, lighting and armatures, fabrics, vegetation, artwork and decorations, and also colors (Pecotic, et.al., 2014).

The existence of interior elements on Instagram also creates an intersection of design principles between spatial design and visual design. Discussing about the interior space in photography is embedded to the elements of photography itself. Both genres believe that principles such as rhythm, balance, contrast, pattern, and unity are parts of their design nature, but the camera angle limits photography to capture only partial elements of the product of interior design. On the contrary, technical restriction in photography can also be a stimulus in creativity to create a visual composition that is very essential for capturing aesthetic photographs that create a response of appreciation to the viewers (Riaz, et. al, 2015).

A reputable photographer, Tom Ang (2013) includes composition as one of the skills to master in photography, which includes the aspects of: 1) Format and proportion: square, landscape, portrait, panoramic. 2) Balance and imbalance: using the rule of thirds, golden thirds, or deciding the image to be symmetrical. 3) Shape within the image: consisting the outer frame and the forms that fill the picture plane, such as vignetting, squared interior, radial, axial, and triangular composition. 4) Suggesting movement: static or dynamic, multiplying parallels, linear, and flat space. Position and perspective, and Composing with colors.

Since Instagram is a photography-based social media application, applying one of these aspects is necessary for creating aesthetic visual experience.

\section{RESEARCH METHOD}

This research is performed with a mixed method through content analysis and with using the word cloud text analysis software as the data analysis tool. Although the nature of the study is qualitative, the instrument for the data analysis is quantitative.

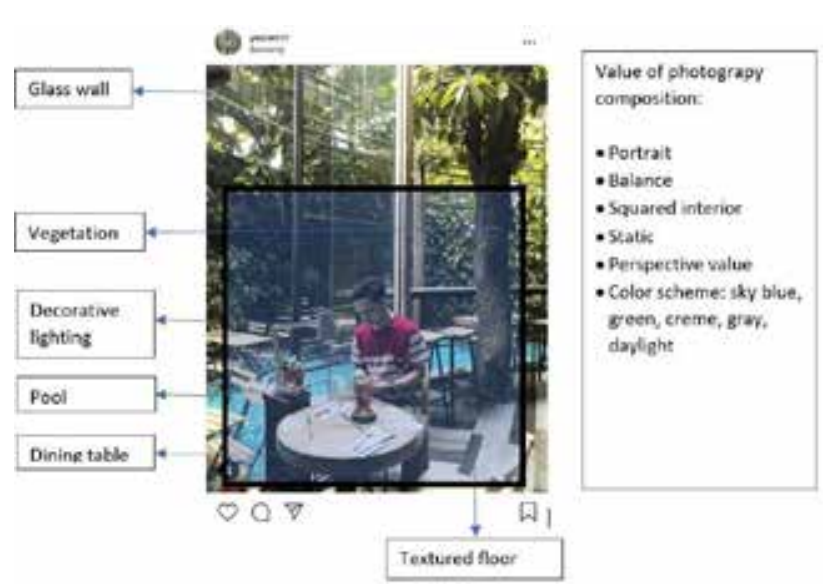

Figure 1 Analysis process (Source: instagram screenshot, 2018) This research consists of two steps: Observing photos of contemporary coffee shops through content analysis method to explore the interior elements included in the photos and how those elements are presented according to the principles of photography (Figure 1). The samples of the coffee shops are 180 Coffee and Music, Mimiti Coffee and Space, Sejiwa, and Sydwic. There are 100 Instagram photos which consist of 25 random photos taken from each of the coffee shops' hashtags. Calculating the textual result from the previous process aided by the word cloud text analysis software at tagcrowd.com. The results then will show the findings of this study.

\section{RESULT AND DISCUSSION}

Every coffee shop in this study is designed in a style that represents contemporary era. Even so, each of them has its own specific approch in creating their visual expression that may stimuate their visitors to take a photo of their places.

\section{Coffee and Music}

This coffee shop is designed in an ecclectic manner that combines a masculine industrial style with varieties of materials and design elements. Bricks, concrete, glass, and black- painted alumunium and steel are materials that can easily spotted inside its interior, but the most interesting part of this place is the outdoor pool dining area where guests can keep their feet inside the water while having their menu.

The word cloud text analysis software generates that black is the most frequent word thatappears on the content analysis stage. Although black is not an interior element, it is attached as the color of several interior elements, such as the feet of the dining tables and chairs, the frames of the glass wall, the material of the stairs, and the color of the exposed ceiling and conduits.

The second elements related to interior shown on the result are dining chair, dining table, vegetation, and textured floor, which appear in a similar frequency. The dining chairs and dining tables carry the black color on their 


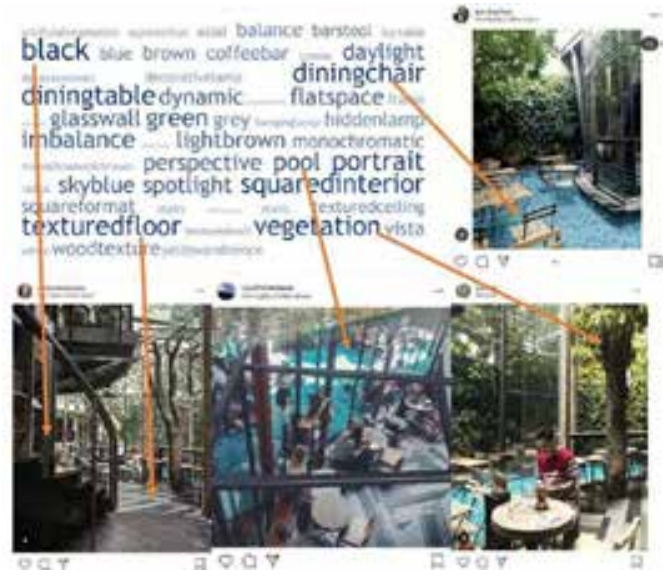

Figure 2 Word cloud text analysis result for 180 Coffee and Music (Source: tagcrowd.com and Instagram screenshot, 2018)

structure frames, so the significant elements shown on the photos of 180 Coffee and Music are the textured floor and the vegetation, which can be seen on Figure 2 .

\section{Mimiti Coffee and Space}

Even though one of the buildings in the area of Mimiti Coffee and Space is a renovated colonial building, the style of the coffee shop in over all of the area expresses a minimalist approach which is blended with the tropical-colonial style. To balance the height of the colonial building, Mimiti is formed as a one-storey floor coffee shop with a high ceiling. The implementation of minimalist style creates a wide planar expression of the floor, walls, and ceiling that appear as flat surfaces in the interior.

Mimiti is also popular for its outdoor seating area. The outdoor dining tables and benches are made of iron, concrete, and unpainted wood. The shapes are clean and the colors appear monochromatic. In the same area, several thin and tall trees are planted between the benches to add a fresh color. The contrast between green and monochromatic colors from the leaves and other materials enhance the expression of minimalist style of the architecture.

The word cloud text analysis for Mimiti Coffee and Space shows "daylight" as the word that appears most frequent. With an outdoor seating area as the center of the space, Mimiti is best experienced in the morning to afternoon during the natural daylight time. It is seen from the captured photos, Mimiti's guests prefer exploring the visual frame of the space in the daylight. Meanwhile, the most frequent word that represents an interior element in Mimiti is the concrete wall. It is clearly seen from the samples that all photos have some part of the concrete wall in the frames, mostly as the background for the photos (Figure $3)$.

\section{Sejiwa}

Having been visited by Indonesian president Joko Widodo (tribunnews.com, 2017), Sejiwa successfully attracts peo-

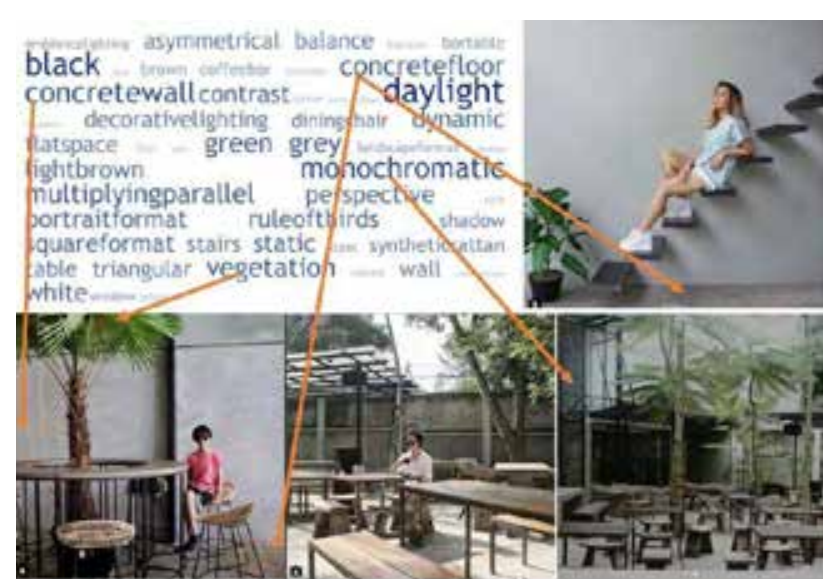

Figure 3 Word cloud text analysis result for Mimiti Coffee and Space (Source: tagcrowd.com and Instagram screenshot, 2018)

ple to come and taste the coffee in this place. From the photos of Sejiwa, we can see that white is the dominant color of this place, complemented by the warm toned wooden materials of the legs of the chairs and tables. All of the walls are made of glass and are exposing the structure of the building which is made of white-painted steel frames. The combination of the glass and white color make the space look bright. The daylight is able to penetrate freely to the interior space and the white color helps reflect the daylight all over the space to create brightness.

Similar to Mimiti Coffee and Space, Sejiwa also expresses a minimalism through the simplicity of the colors, but this coffee shop also has some decorative spots, such as an application of a mural on a tall concrete wall and an appearance of a scooter as a decorative installation. With a combination of a minimalist style and a touch of decoration, people are drawn to explore the geometric composition of the interior space and place a human figure as the point of interest. An object on the photo may appear as a visual contrast or as a unity to the whole image.

In line with the explanation about the brightness of the space, the word clout text analysis shows "daylight" as the word that appears most frequently, followed by "white". The next word shown on the analysis tool is "glasswall" (Figure 4). This is the first word that is related to interior element. Its appearance on almost every photo is not surprising since the whole space of the building is enclosed with it. With using a concept of an open space, a glass wall as the boundary of the space will always be seen on the photo regardless the photographic angle.

\section{Sydwic}

Although the size of the building is small, Sydwic appears to be very eclectic and decorative. Similar to Sejiwa which is dominated by white as the main color on the palette, but Sydwic has more additional monochromatic color from its interior elements. With so many elements, Sydwic tries to balance the monochromatic look with more textures and 


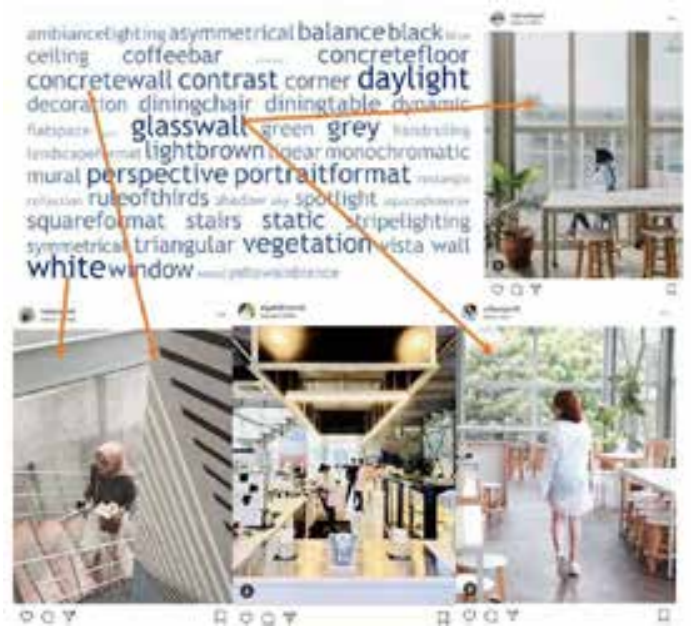

Figure 4 Word cloud text analysis result for Sejiwa (Source: tagcrowd.com and Instagram screenshot, 2018)

patterns from many interior elements, such as wall decorations, varieties of hanging lamp armatures and vegetations, and the use of multiple colors with pastel tone on the furniture.

Compared to the rest of the coffee shops, Sydwic has a scale of space that is very intimate. If the previous three coffee shops use many stools for the seats, Sydwic use a lot of sofas that make a statement of its coffee shop typology. Whereas

coffee shops with stools and minimalist design are easily associated with a coworking space, coffee shops with many sofas and decorations are meant for lounging as if in the living room.

The decorations, the intimate scale, the sofas, and the pastel toned colors in Sydwic make the interior of this coffee shop look feminine and warm. Even though "daylight" still dominates the preference of the photo setting, it is seen from the result of the word cloud text analysis that there are many interior elements that appear in a similar frequency on Instagram photos, such as "hanging lamp", "vegetation", "concrete wall", "wall decor", and "decorative lamp". It means the interior of this coffee shop has many attractive objects that make the visual appearance of the space photogenic (Figure 5).

\section{Preferable interior elements}

Through analyzing the content of the photos per coffee shop, we have seen that there are several elements that always appear on the analysis tool. The word "daylight" always comes as the most frequently seen for the context of the photos. Although it is not directly related to the visual interior element, it has an important role to indicate that whether it is seen or not, the design of the interior elements should enable the natural daylight to penetrate as much as possible to the space of the coffee shops. This result is also seen from the word cloud text analysis tool that generates the whole content from all coffee shop samples (Figure 6).

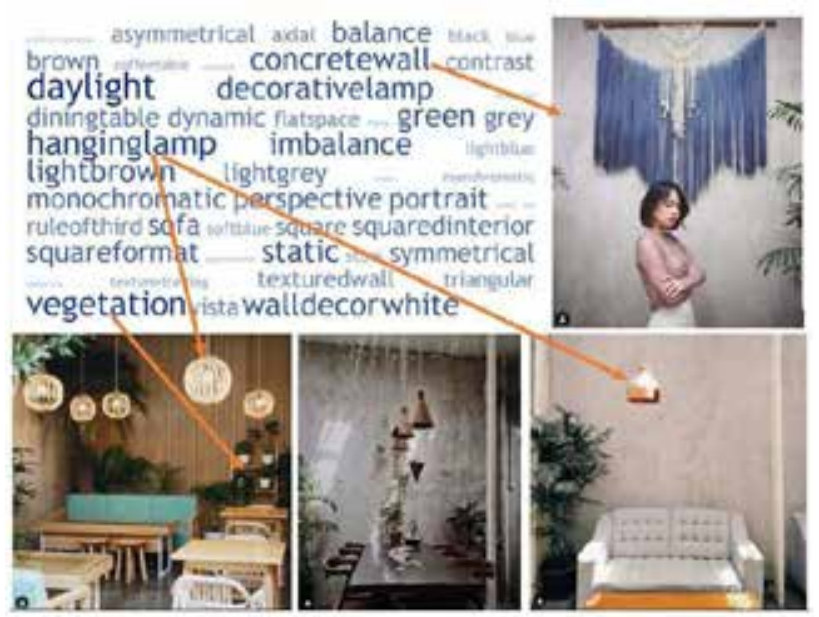

Figure 5 Word cloud text analysis result for Sydwic (Source: tagcrowd.com and Instagram screenshot, 2018)

Unexpectedly, the first interior element that appears the most frequently of all photos is vegetation, which comes from a natural element. Its existence in the interior comes mostly in a form of decoration to fill the corners of the spaces. An exception is found at 180 Coffee and Music where vegetation becomes a part of the architecture. The building includes an existing tree trunk in the indoor seating area, meanwhile the outdoor seating area is surrounded by vertical garden.

The first noun that appears to be the most preferable manmade interior is "concrete wall". It appears in a similar frequency to other words that represent the character of the photos, such as "perspective", or words that represent the colors of the elements on the photos, such as "black", "light brown", "green", "grey", and "monochromatic".

From the photo samples, it is rarely seen that a photo only consists of an element. Therefore, vegetation and concrete wall are the elements that become a necessity in the interior of a contemporary coffee shop, in order to attract visitors to take pictures and make a posting on Instagram. The colors found in the result refer to the paint and materials used in the interior space and the furniture. Black and white are the colors of the painted steel for the building and the furniture structure; meanwhile light brown is the color of the wood, green is the color of the vegetation, and grey is the color of the concrete, all of which are used in their raw and unfurnished look of furniture and decorations.

Wherever any of these colors are used in the interior space, it creates a monochromatic tone that looks simple in the eyes of the photo perceivers. With an appearance of a concrete wall as the background, it creates a clean boundary in a neutral grey color that supports the simplicity of the image. Observing from the photo samples, the simplicity of the tone allows an addition of a human figure in the photo frame becomes contrast and can be the focus of interest of the photo. This outstanding attention of a human figure 


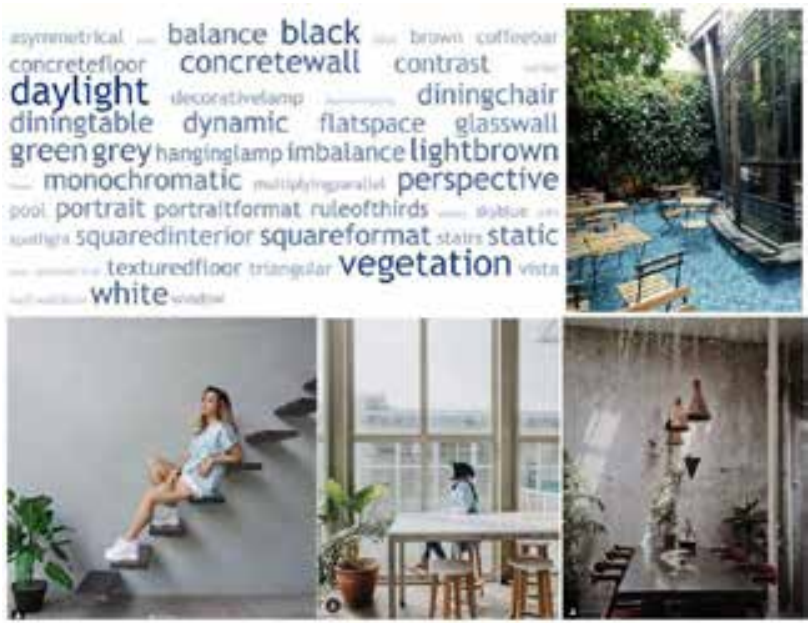

Figure 6 Word cloud text analysis result for all coffee shop samples (Source: tagcrowd.com and Instagram screenshot, 2018)

in a frame is what is needed for a self-expression. Thus, coffee shops that have this interior setting are preferred to become a photography object which relates to the need of self-expression in today's culture.

\section{CONCLUSION}

The result generated from the word cloud text analysis software shows that vegetation and concrete wall have become the most preferable interior elements on Instagram photos at contemporary coffee shops. Even so, the appearance of these elements is usually accompanied with any other of interior elements, mainly furniture. Any furniture may appear in manycompositions depending on the unique theme or style of the coffee shop itself, but a monochromatic look in the color tone is preferred as a photography background, since a human figure may appear as the point of interest for self-expression. With this result, it is suggested that both designers and coffee shop owners consider to implement these elements to the coffee shop interior space in order to attract visitor to make Instagram posts that will keep the continuation of this business industry.

With the context of contemporary design that keeps changing in style, this research still has limitations in term of the longevity of the preferences and the occurring design style in the studied samples. The context of this study is attached to the regional culture of people in Bandung with their aesthetic style preferences and lifestyle.

\section{ACKNOWLEDGEMENT}

This research is a supporting part of an internal research project about styles of contemporary coffee shops in Bandung, funded by Telkom University.

\section{REFERENCES}

Agam, Darel N.L.A. (January 2017), "The Impact of Viral Marketing Through Instagram", in Australasian Journal of Business, Social Science and Information technology (AJBSSIT), 4/01, pp. 40-45.

Ang, Tom (2013), Digital Photography Masterclass, Dorling Kindersley Limited, Great Britain.

Çelik, Sabahattin (March 2017), "The Usage of Instagram as a Marketing Tool", in Journalism and Mass Communication, 7/03, pp. 133-141.

Clara, Ana (2017), "Stories We Tell Our Selfies", in The Asian Conference on Arts and Humanities 2017 Official Conference Proceedings, pp. 378- 383, IAFOR, The International Academic Forum.

Coles, John and House, Naomi (2007), The Fundamentals of Interior Architecture. AVA Publishing SA, Switzerland. Dodsworth, Simon (2009), The Fundamentals of Interior Design, AVA Publishing SA, Switzerland.

Hendriyani, I. G. A. D. (2018), "The Importance of Physical Environment for Guest Satisfaction on Restaurant in Bali", in 2nd International Conference on Tourism, Gastronomy, and Tourist Destination (ICTGTD 2018) Advances in Economics, Business and Management Research (AEBMR), Vol 52.

Khairani, Zulia, et. al. (Februari 2018), "Efektivitas Promosi Melalui Instagram pada UMKM Sektor Makanan dan Minuman di Kota Pekanbaru", in Jurnal Benefita, 3/01, pp. 239- 247, Kopertis Wilayah X.

Kim, Seungbae, et. al. (September 13-15, 2017), "How Are Social Influencers Connected inInstagram?", in Social Informatics, 9th International Conference, SocInfo 2017, PartII, LNCS 10540, pp.257-264.

Lisdayanti, A and Anwar, T.A. (2018), "Increasing Public Awareness of Consuming Indonesian Coffee through Electronic Marketing", in 2nd International Conference on Energy and Environmental Science, pp. 1-6, IOP Publishing.

Nisak, Khoirun and Hariyanto, Didik (September 2017), "Food Photography and Eating Out di Media Sosial Instagram", in KANAL, Jurnal Ilmu Komunikasi, 6/01, pp. 31- 40 .

Pecotic, M., et. al. (2014), "Interior Design in Restaurants as a Factor Influencing Customer Satisfaction", in RIThink, 2014, Vol. 4, pp. 10-14. Croatia: Rochester Institute of Technology. 
Purnomo, Mangku (2018), “Contesting Indonesia’s Single Origin Coffee Market: A Dynamic Capabilities Perspective", in Asian Social Science, 14/08, pp. 91-101, Canadian Center of Science and Education.

Riaz, Sidra, et. al. (2015), “A Photograph Reconstruction by Object Retargeting for Better Composition", in Multimed Tools Appl, Springer Science+Business Media, New York

Rohman, Abdul and Pang, Natalie (November 6-10, 2015), "Seeking Common Ground: Coffee Shops as Information Grounds for Peace in the Conflict Zone", in ASIST Proceedings.

Rosiana, Nia, et. al. (December 2017), “The Level of Comparative Advantages of World Main Coffee Producers", in Buletin Ilmiah Litbang Perdagangan, 11/02, pp. 227-246.

Suess, Adam (2018), "Instagram and Art Gallery Visitors: Aesthetic experience, space, sharing and implications for educators", in Australian Art Education, 39/01, pp 107122.

Zappavigna, Michele (2016), "Social Media Photography: Construing Subjectivity in Instagram Images", in Visual Communication, 15/03, pp. 271-292, Sage Publishing, UK.

Fatimah, Siti. (December 5, 2017), Daftar Kopi yang Dipesan Jokowi...http://www.tribunnews. com/ nasional/2017/12/05/daftar-kopi-yang-dipesan-jokowi-saat-mampir-ke-sejiwa-coffee-salah-satunya-kopi-puntang 